\title{
Panchayat Jagratha Samithi role on Violence against Women and Children in Kerala
}

\author{
Titty Varghese \\ Kaunas University of Technology \\ Mickevičiaus g. 37, Kaunas, Lithuania
}

cross $^{\text {ref }}$ http://dx.doi.org/10.5755/j01.ppaa.20.1.28262

\begin{abstract}
The Indian state Kerala is renowned for its overall development in various indexes such as human development, equality and education. However, in terms of combating violence against women and girls, state policies do not fulfil their objectives. The total number of crimes against women in Kerala during 2007 was 9381, by the end of 2019, it had risen to 13925, and by October 2020, it was 10124. To prevent all forms of crimes against women, the state established a vigilant committee in 1997 under Kerala Women's Commission's supervision. This vigilant committee is known as Jagratha Samithi (in the Malayalam language) and works in every Local Self Government (Panchayat). Therefore, the object of this research is the Jagratha Samithi (JS). The study aims to identify the JS's role and activities in a panchayat to prevent violence against women and children. The methodology of the research is based on a qualitative study with primary data collected from 40 elected female and male representatives from 35 panchayats from one district in Kerala. The study shows that Jagratha Samithi in a panchayat has a significant role in addressing crimes against women and girls. However, there is a lack of sufficient support from society on its mission.
\end{abstract}

Keywords: Jagratha Samithi, violence against women, panchayat, gender policy, Kerala Raktažodžiai: Jagratha Samithi, prievarta prieš moteris, panchayat, lyčiu politika, Kerala

\section{Introduction}

Article 1 of the United Nations General Assembly resolution identifies violence against women as "any act of gender-based violence that results in, or is likely to result in, physical, sexual, or psychological harm or suffering to women, including threats of such acts, coercion or arbitrary deprivation of liberty, whether occurring in public or private life." In India's case, the National Crimes Records Bureau (2018) of India found out that crimes against women happen every 1.7 minutes in any part of India. Every 16 minutes, a woman is raped and every 4.4 minutes domestic violence occurs. According to the National Population Register, in Kerala, the sex ratio is 1058 (women) per 1000 (men). However, it is only 914 per 1000 males for the whole of India. Studies show that domestic violence is a prevalent form of violence (George, 2011; Sunny, 2003). Many married women who are victims of violence commit suicide due to various forms of torture in Kerala (Indu et al., 2020). The patriarchal ideology of gaining more control over women caused an increase in the violence against women (Hunnicutt, 2009).

In most cases, the intimate partner is the main offender. Despite various developments in society, different forms of violence against women and girls are increasing day by day in Kerala. This must be adequately addressed, and strong government policies need to be taken to prevent abuse against women and girls. In this context, the significance and responsibility of Jagratha Samithi' (in English: Vigilant Committee) gained much attention. It formed at the panchayat level of Local Self Government in 2007. Panchayats should protect women's rights and empower them in India (Usha, 
2012; Venugopal \& Yilmaz, 2009). In Kerala's case, women's access to politics in the panchayats has increased their chance to raise voice against oppression (Devika \& Thampi, 2011; Nair \& Moolakkattu, 2014). JS is a project of the Government of Kerala designed to prevent various crimes against women and intervene in the atrocities and violation of human rights of women in multiple spheres of society in all local bodies, particularly in all panchayats. However, few studies (Chacko Jose, 2020; Nair \& Moolakkattu, 2014; Subair, 2017) on the JS and its importance on preventing violence against women in Kerala's panchayats have been conducted. Therefore, this paper focuses on analyzing the JS in a panchayat to prevent violence against women.

The research object of this article is the functions and the role of Jagratha Samithi (JS).

This article sets the following aims:

1. To identify the magnitude of violence against women and children in Kerala.

2. To address the importance of the JS in a panchayat on preventing violence against women.

3. To identify the JS activities in a panchayat.

To determine the aims specified, it is essential to conduct an empirical study at the panchayats to identify the JS activities at Kerala's panchayats. The article demonstrates that the JS committee can take care of violence against women in panchayats. This article extends research based on the primary data collected from 35 panchayats from the Idukki district of Kerala state in India. Many studies (Ahmad et al., 2019; Bhattacharyya, 2016; Nieder et al., 2019) reveal that violence against women in India is alarming. The Dowry system is considered one of the critical reasons for various forms of marital violence in India (Banerjee, 2014; Rastogi \& Therly, 2006; Rudd, 2001; Sharma et al., 2005). Apart from that, child marriage and various forms of crimes against women's children, including female fetus abortion, are also prominent in India. The patriarchal mindset of Indian society stood as one of the reasons for the prevalence of increasing child marriage in India (Barnes et al., 2011). As men in India possess more independence and opportunities to engage in society than women, women have fewer options and desires and are more vulnerable and accountable to their families and husband. Therefore, scholars (Jejeebhoy \& Sathar, 2001; Kabeer, 1999, 2005) reveal that women gain power and control over their own lives if they have enough money, education, welfare, compensated assets and property rights. If this is the case, they will be able to move on with their lives instead of being tied up in various violent situations. There are a few studies on the role of the JS in a panchayat (Biju \& Kumar, 2013; Chacko Jose, 2020; Joseph, 2020). However, the study on the JS's role in preventing violence against women and children in panchayats is yet to be explored. Therefore, this research is trying to evaluate JS activities and the policy's importance in society.

\section{Methodology}

This paper uses United Nations definitions of violence against women. To identify the crime against women and girls in India, it uses the crime statistics reports issued by the National Crimes Records Bureau of India. The number of crimes against women in Kerala was obtained from the official Kerala police web portal. To analyze the role of JS in preventing violence against women and girls, this paper seeks to find out what activities were implemented by the JS at the panchayat level by referring to the mandates issued by the Government of Kerala. To find out the importance of JS and their activities in the panchayats, it was essential to visit and analyze the works of elected women and men representatives at panchayats. Therefore, an empirical study was conducted from 35 panchayats in the Idukki district of Kerala. Semi-structured interview were carried out with a total of 40 elected women and men representatives. Among them, 25 were women and 15 were men; the interviewees held the leadership at the panchayat as a president/vice president /member of the wards between 2015 and November 2020. The panchayat president is the chairperson/chairman of the JS committee in every panchayat. Therefore, among a total of 40 respondents, 30 were panchayat presidents ( 25 women and 5 men), 4 vice-presidents ( 2 women and 2 men), and 6 were ward members who are also part of the ward level JS committee ( 2 women and 4 men). The primary interviews were 
collected in 2019 and were conducted in the Malayalam language, Kerala state's official language. The discussions with the elected representatives of the panchayat elaborated on the importance of strengthening the JS in their respective regions for preventing all forms of violence against women and girls under their leadership. Observation of various events, seminars and awareness programs at the panchayat were part of this study. Table 1 specifies the socio-demographic characteristics of the 40 respondents.

Table 1. Socio-demographic characteristics of the respondents

\begin{tabular}{|l|l|l|l|}
\hline \multicolumn{1}{|c|}{$\begin{array}{c}\text { SOCIO-DEMOGRAPHIC } \\
\text { CHARACTERISTICS }\end{array}$} & \multicolumn{1}{|c|}{ CATEGORY } & FEMALE & MALE \\
\hline Total respondents & & 25 & 15 \\
\hline Age & Age Under 30 years & 2 & 0 \\
& $30-39$ years old & 2 & 1 \\
& $40-49$ years old & 10 & 5 \\
& $50-59$ years old & 10 & 8 \\
& 60- 69 years & 1 & 1 \\
& $70-79$ years & 0 & 0 \\
\hline Education & Up to high school & 7 & 13 \\
& Secondary school Diploma & 10 & 2 \\
& University education & 5 & 0 \\
& Professional training & 3 & 0 \\
\hline Family status & Married & 24 & 13 \\
& Not married & 0 & 2 \\
& Widow & 1 & 0 \\
\hline Employment & Employed & 12 & 15 \\
& Unemployed & 13 & 0 \\
& Retired & 0 & 0 \\
\hline Any political party affiliation & Other & 25 & 0 \\
\hline Religious group affiliation & Yes & 18 & 7 \\
\hline Other organizational leadership & No & 22 & 7 \\
& Yes & 3 & 12 \\
\hline & No & & 3 \\
\hline
\end{tabular}

Source: Author.

\section{Results}

\section{Violence against women and children in Kerala}

The Department of Women and Child Development of the Government of Kerala (WCD, Kerala) identified that the misconceived notions of gender roles pose deep concerns about protecting women and children. Various forms of sexual harassment, rape and abuse against women and children are profoundly rooted in various parts of the globe and patriarchy is one of the main challenges in Kerala as well. Figure 1 shows the various forms of crimes against women in Kerala from 2010 to October 2020. Despite the high ranking in developing multiple types of development, an increasing number of crimes against women and girls in Kerala can be seen every year. Various forms of mental and physical abuse and insecurity are a barrier for women in society. Rape, molestation along with cruelty by husband or his relatives are also alarmingly high. Even though the number of dowry-related deaths decreases, there are still many incidences of dowry-related crimes against women in Kerala (Bradley \& Pallikadavath, 2013). 


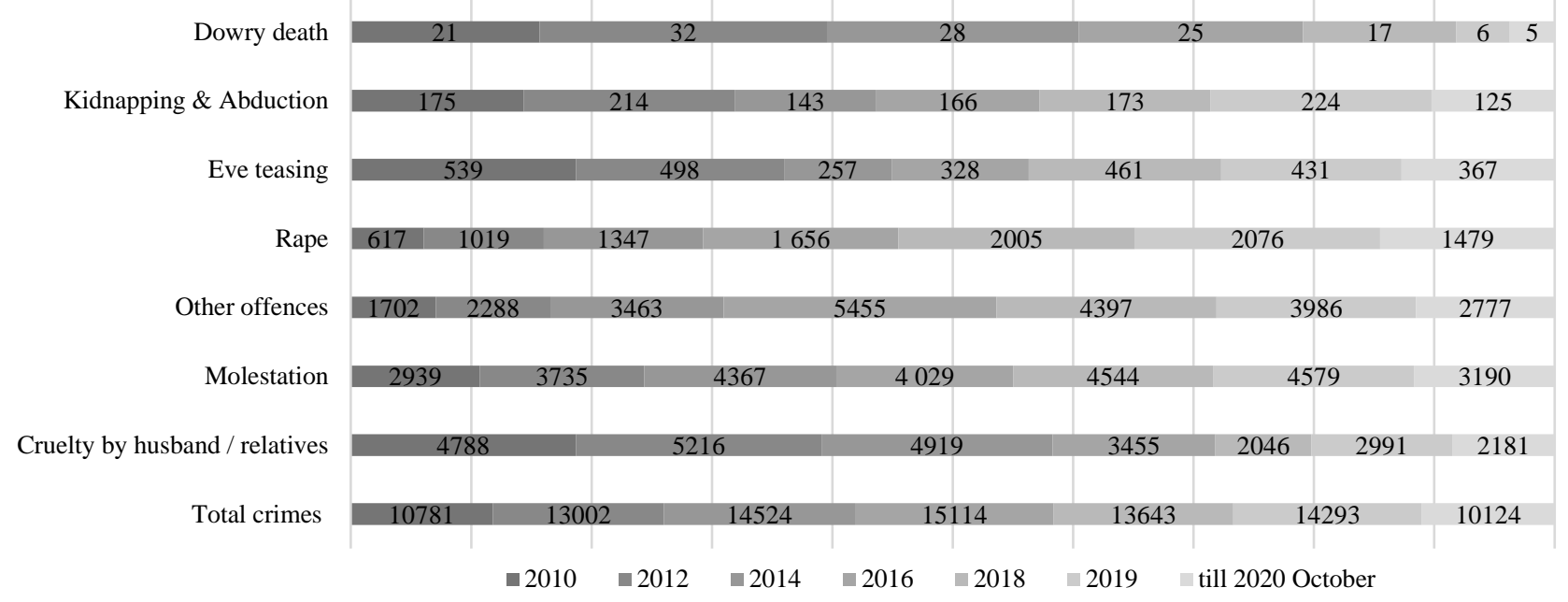

Fig. 1. The number of crimes against women in Kerala, 2010-October 2020

Source: Official Website of Kerala Police.

Since various forms of abuse against girls and boys are also a significant issue in Kerala, Figure 2 shows the number of crimes against children in Kerala, 2010-2019.

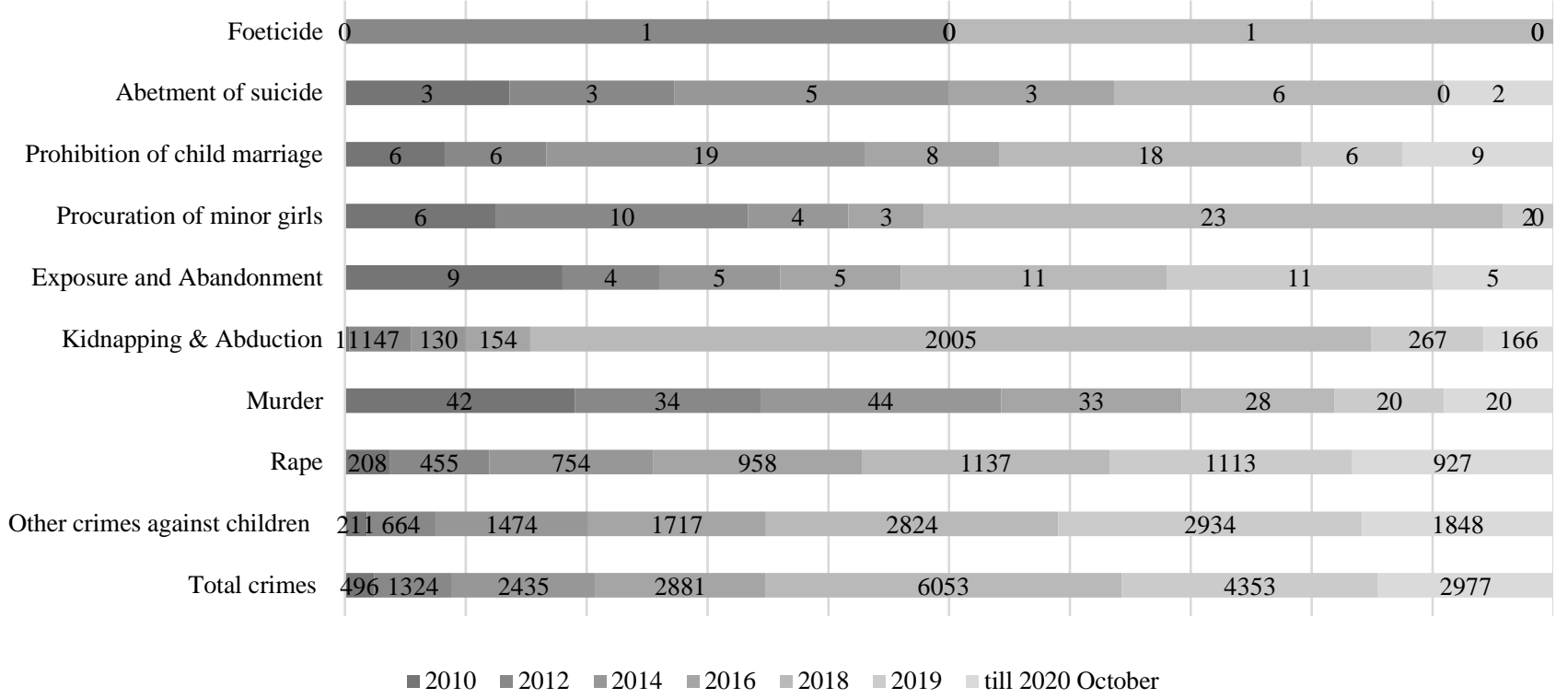

Fig. 2. The number of crimes against children in Kerala, 2010- 2019

Source: Crime Against Children, Official Web portal of Kerala Police.

The findings indicate that the number of crimes against children in Kerala increases yearly, such as physical and psychological abuse, especially rape, kidnapping, murder and child abuse. They also shows that in some parts of Kerala, children are still victims of child marriages even though child marriage is prohibited by law. Figure 3 shows the percentage of women who sought help in Kerala during 2015-16 when they faced any type of violence. Women who have been subjected to some form of physical or sexual abuse should share their concerns with someone. The study shows that women's insecurity in Kerala society is the reason why only about $25 \%$ of women have spoken and requested help if they have experienced physical abuse. It is a matter of concern to the Kerala community that in the case of non-married persons who have often been subjected to some sort of sexual harassment, they do not want to share the same problems with another person or do not try to get help. It is a worse situation when people do not report their real-time issues due to various crises or for fear of being mistreated. Importantly Kerala society still views girls who have been bullied as experiencing 
bullying because of their own misconduct. Therefore, girls are afraid to speak out about physical or sexual abuse to someone else or to talk about it to their own family. The fact that the perpetrators of such situations can easily exploit the girl again and again or even jeopardize their health is another fact that is seen daily in various media and discussions. Due to these reasons in most of the cases, women are afraid to go to the police station and report the atrocity (Carbone-Lopez et al., 2016; Córdova \& Kras, 2020; Jordan, 2004).

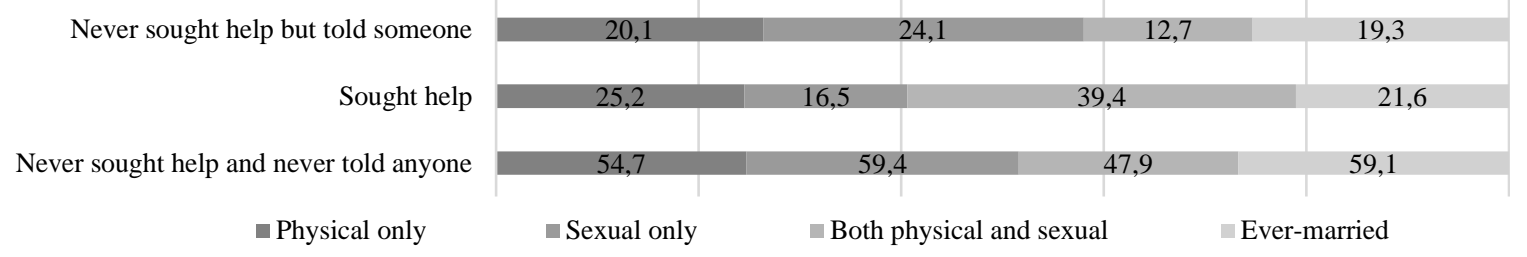

Fig. 3. The percentage of women who sought help in Kerala during 2015-16 Source: National Family Health Survey, Kerala, 2018, p. 154.

Figure 4 shows the percentage of women aged 15-49 who have experienced physical or sexual violence. It also indicates whether they have ever sought help. Among those who have tried service from any source, the source from which advice was found is indicated according to the type of violence experienced and marital status, Kerala, 2015-16 (NFHS, Kerala, 2018, p.44). As we can see from the result, about $71.7 \%$ of women depend on their own family for assistance when they need it, while only $23.9 \%$ seek help from their husbands' families. It is mainly due to the cultural stigma that the communication or close connection between a married woman with her husband's family is less than that of her parents and family and the husband's family can be violent towards the bride (Fernandez, 1997). About 13.6\% seek legal help from a lawyer or court, 6.2\% seek assistance from their friends, $5.9 \%$ from their neighbours, and there is only $5.5 \%$ of women who sought help from the police. Most victims are afraid to go to a police station and complain about their husbands or inlaws or face any other forms of violence in society. This is mainly due to the lack of sufficient support and awareness of the help that can be received from the police. Victims fear being shamed in society or by the media. The victim's family also prevents the victims from reporting violent incidences to the police due to various reasons mentioned.

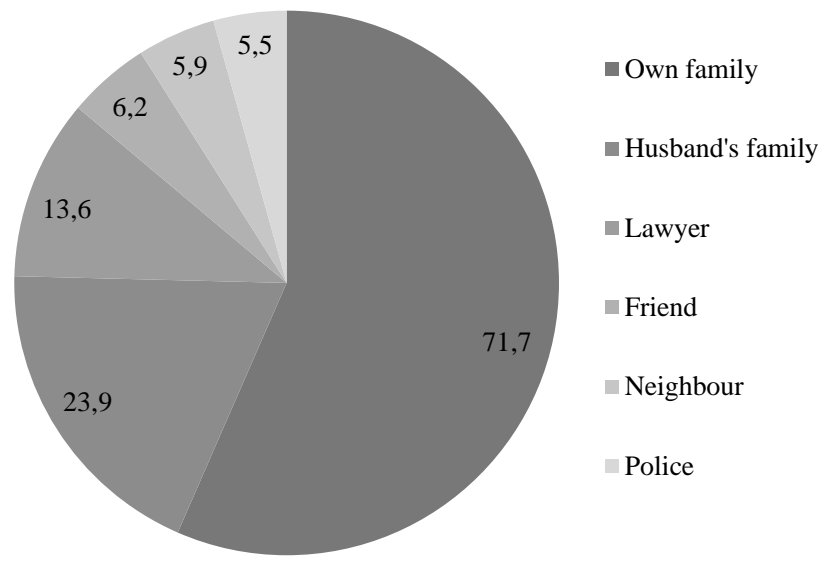

Fig. 4. The percentage of women who sought any help in Kerala during 2015-16 Source: National Family Health Survey, 2018, p. 154.

\section{Jagratha Samithi and its role in combating violence against women}

In the past twenty years of decentralization and power distribution through the Panchayati Raj Institutions (PRI), there have been many benefits to society from the local self-government (LSG) in the south Indian state Kerala. However, it is undeniable that various forms of sexual harassment, child 
marriage, harassment and domestic violence are still factors that make hurdles for the development of women in Kerala, despite their higher literacy rate at the national level. Preventing such offenses can also be achieved with governmental policy, economic assistance and cultural transition towards gender equality. Therefore, the government considered the protection of women and children and their development as one of the most critical missions. Kerala Woman Commission has come up with various schemes for combating violence against women and girls in Kerala from time to time. However, due to the increasing number of cases, the commission has not accurately provided justice to victims.

The Jagratha Samithi (vigilant committee) was formed in Kerala in all districts and local level boards in 1997 in 832 panchayats. The composition of the JS is as follows: the women's commission is in the most responsible position. Below is the district JS. Under it, the Local Self Government Organization in a panchayat level comes and below that, there is a group at the ward level. A panchayat JS has two different departments. The panchayat JS was formed to assist its various wards. The ward JS committee addresses each ward's concerns (neighbourhood) and brings them to the panchayat level. The JS Head Committee of the Panchayat consists of 9 members: grama panchayat president, convener, Integrated Child Development Scheme (ICDS) ${ }^{1}$ supervisor, police inspector or sub-inspector, social worker, doctor, Community Development Society (CDS) ${ }^{2}$ (Kudumbashree Story - Community Development Society) chairperson, ward-level JS and Schedules Castes and Scheduled Tribes (SC/ST) representative (Kerala Legislature Secretariat, 2015).

The JS operates from the panchayat level and is responsible for assisting victims of violence. It is a severe and dangerous trend that, often due to legal hurdles, lack of financial security to proceed with the case and social stigma and prestige, violence occurs in many situations.

However, the panchayat-level JS has been given the authority to make decisions in such cases and provide all necessary protection to women. Separate funds and projects are given to each panchayat. The objectives and duties of the JS are as follows:

1. Accept and resolve complaints made by women and girls,

2. Identify/intervene to solve problems,

3. To ensure that there is no violence/violence against women and girls,

4. Help the three-tier panchayat to prevent problems/atrocities against women and girls,

5. Provide necessary legal assistance, advice and information.

Before discussing the members of a panchayat JS and their duties, first of all it is necessary to examine the Samithi chairperson's, who is always the panchayat president, functions. He or she must preside over JS meetings, lead the activities and use the power to ensure that the work is efficient and effective. Also, s/he conducts political and social interventions to resolve the problem and ensure that the governing body is aware of everything, except the activities that need to be secret. Then there must be a police officer in the JS. S/he must summarize all the JS events, act when the complaint is registered and provide the police services. Furthermore, there must be a lawyer in the JS. S/he must conduct legal awareness camps to give free legal advice to victims and formulate a committee to assist with all laws and mechanisms. The lawyer is also responsible for providing legal books, pamphlets about human rights and victims' protection. Each ward must have a JS. It is the responsibility of each ward's representatives to promptly inform the panchayat, to assist the panchayat in dealing with issues and resolve the crimes against women and girls in their ward.

In addition, a panchayat JS must have a doctor. It is the responsibility of a panchayat primary care physician or doctor to study the health problems in an area or panchayat. The doctor is also

\footnotetext{
1 Integrated Child Development Scheme (ICDS) established in India under the Ministry of Women and Child Development in 1975 for childhood development by addressing malnutrition, health and assistance to pregnant and nursing mothers.

${ }^{2}$ Community Development Society (CDS) is the 3-tier Kudumbashree community organization's apex body. It operates geographically, in both rural and urban areas.
} 
responsible for alerting the JS committee to be aware of the causes and consequences of epidemic diseases. The ward-level JS establishes relationships with representatives and takes initiatives to address issues in their respective wards. It is also the SC/ST division's responsibility to bring women who belong to the SC/ST group. This representative is responsible for awareness development and forward any grievances to the panchayat level authority efficiently. The panchayat president must work hard for the upliftment of women and children in a panchayat. It is essential to take all necessary steps to protect, mobilize the social service and arrange various spokespeople levels. Financial aid is vital for the functions of the JS. Funds from the state government, local government or public institutions are used to finance the JS work. The JS has no right to accept any donations from private entities under any circumstances.

The JS is entitled to fulfill various duties, mainly to receive complaints against women in multiple ways. Complaints are accepted in letters directly or indirectly. The JS has all the right to file a case against any crimes against women, which occurs in their panchayat, even if the victim did not make a complaint. In these cases, the name of the victim is replaced with the JS's name. There is a constant requirement of JS gathering and hence attendance must be taken at least once a month, i.e., the interval between the two meetings should not be longer than 30 days. If there is an urgent need, the JS can be conducted immediately without any prior notification to the other members. The JS is responsible for considering violence against women, i.e., within 24 hours of any such incident. The emergency meeting should co-ordinate immediate action taken depending on the urgency of the case. They must provide medical care within 24 hours, provide initial support and follow-up and seek medical attention within 24 hours of a harassment case, including rape. The JS ensures that the victim received the First Information Report (FIR) when they submit it to the police. If there is a need for a resolution to the church or a compromise committee, the committee may appoint a subcommittee of not less than three members, including the convenor and not less than five members.

To strengthen the linkages between the panchayat, municipality and district JS's support of the empowerment, they should partner with the three-tier system, self-help groups Kudumbashree ${ }^{3}$ (Local Self Government Department, Kerala) systems, NGOs, and other development agencies. To assist the JS with such activities, the panchayat shall constitute an assistance committee (in Malayalam, sahaya samithi) and a legal assistance committee (in Malayalam, niyama samithi) in the Local Self Government Institution. It should provide guidance and support for their activities. At the panchayat, municipality and corporation, the JS does not have a fixed term. The committee may change their position of office, either with relocation or for some other reason. If there is a shortage of one member of the panchayat, the vacancy must fill within one month. The ward JS's annual meeting shall meet each year to evaluate each member of the JS's activities.

\section{Case study: the Idukki district}

To achieve the second objective of this research, which is to identify the JS activities, it is essential to determine the number of crimes against women in the Idukki district. Below, Figure 5 shows the number of crimes against women in the Idukki district from 2010 till 2020 March, as per the Kerala Police reports.

\footnotetext{
${ }^{3}$ A community organization utilizing Neighborhood Groups (NHGs) has proven to be a successful strategy for the empowerment of women in both rural as well as urban areas.
} 


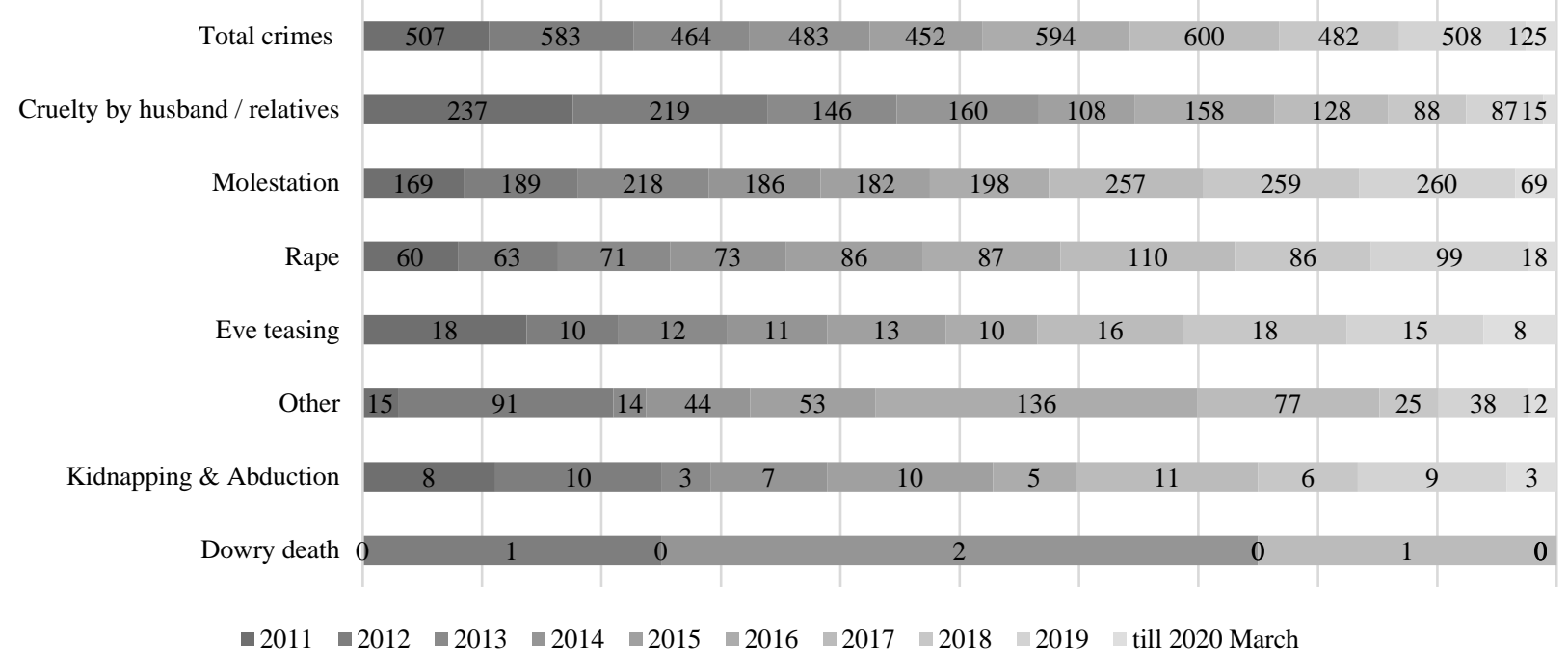

Fig. 5. The number of crimes against women in Idukki district 2010-June 2019 Source: Official Web portal of Idukki District Police.

Figure 5 identifies that the number of various forms of crimes against women in the Idukki district increases yearly. Cruelty by husband or relatives is a severe form of violence. Molestation and rape crimes also show the importance of awareness-raising programs and motivating the public to report crimes and co-operate with the governmental authority to prevent atrocities against women and girls. Table 2 shows the main activities of the JS in various panchayats of the Idukki district. The given result was obtained through the primary interview with 40 elected women and men representatives at the panchayats.

Table 1. Jagratha Samithi activities in the panchayats from the Idukki district

\begin{tabular}{|c|c|c|}
\hline JS ACTIVITIES & AGREE & DISAGREE \\
\hline $\begin{array}{l}\text { 1. Accept any grievance from women and girls and make necessary interventions and } \\
\text { solutions as soon as possible. }\end{array}$ & 40 & 0 \\
\hline $\begin{array}{l}\text { 2. Create mechanisms to deal with violence, discrimination, exploitation and injustice } \\
\text { against women and children. }\end{array}$ & 38 & 2 \\
\hline 3. Formulate and implement action plans to stop crimes against women and children. & 40 & 0 \\
\hline 4. Create different types of communities to achieve the goal. & 26 & 14 \\
\hline $\begin{array}{l}\text { 5. Help and support the women's organization's activities at the local government } \\
\text { institutions. }\end{array}$ & 29 & 11 \\
\hline 6. Evaluate the gender audit of the activities of the institutions. & 40 & 0 \\
\hline $\begin{array}{l}\text { 7. Inform unresolved grievances and issues to the district vigilance committee, women's } \\
\text { commission, other government institutions and aid centers for follow-up action. }\end{array}$ & 40 & 0 \\
\hline $\begin{array}{l}\text { 8. Create clubs in the local and educational institutions for teenagers and youth to develop } \\
\text { an awareness of gender issues and strengthen their self-empowerment. }\end{array}$ & 26 & 14 \\
\hline $\begin{array}{l}\text { 9. Conducting awareness programs to ensure women and girls' identity, development of } \\
\text { creativity, dignity, status, freedom and security. }\end{array}$ & 37 & 3 \\
\hline $\begin{array}{l}\text { 10. Prevent the dowry system, stop propaganda against women's development, child sexual } \\
\text { abuse, prevent production, distribution and usage of alcohol or drugs or tobacco } \\
\text { products. }\end{array}$ & 15 & 25 \\
\hline
\end{tabular}




\begin{tabular}{|l|l|l|}
\hline \multicolumn{1}{|c|}{ JS ACTIVITIES } & AGREE & DISAGREE \\
\hline $\begin{array}{l}\text { 11. Help the prosecution and other investigative agencies in incidences such as rape, } \\
\text { abduction, disappearance, suicide, murder and sexual assault for swift and transparent } \\
\text { justice for victims. }\end{array}$ & 40 & 0 \\
\hline $\begin{array}{l}\text { 12. Identify publications such as movies, posters, commercials, media reports or articles that } \\
\text { propagate anti-women or violence indictment and seek legal assistance against such } \\
\text { publications. }\end{array}$ & 9 & 31 \\
\hline $\begin{array}{l}\text { 13. Establish gender desks at schools and try to create awareness of mutual respect and } \\
\text { understanding among children. }\end{array}$ & 38 & 2 \\
\hline
\end{tabular}

Source: Author.

While discussing receiving complaints from people who have been abused, one panchayat president said they had a very prominent sexual abuse case in their panchayat.

"Since the victim is under 18 years of age, the parents and family did not show interest in filing a complaint with the police. One of our society's significant problems is that the victims are unwilling to take legal action due to harassment or exploitation or external pressure. They are afraid and hesitant to make official complaints by considering that their problem will be known to the public and possibly through various media. It will ruin their name, dignity and safety of the future. In such a situation, the $J S$ of the panchayat must act very efficiently as the member of a ward has a clear understanding and awareness of what needs to be done. Of course, the ward panchayat member is the first person responsible for resolving such issues and ensuring that no one understands them and acts efficiently".

(Anonymous 1, 2019)

In terms of dealing with any form of psychical or sexual exploitation, another respondent said that,

"Idukki is one of the 14 most populous districts in Kerala and has a large agricultural population, and there are many tea plantations in our panchayats. Many women and girls in my panchayat work in tea plantations and related industries as daily wagers. Most of the residents in my area are from economically backward families, so even if they are children, they do not show any commitment and enthusiasm to study even up to 10th class. Many of the students, of whom women or girls are the most vulnerable, who dropped out of school due to low financial status faced various mental and physical exploitations at their workplaces. The physical and psychological harassment they face in their work goes unnoticed by the panchayat and therefore we often have minimal opportunities to find and assist such people. Because of the fear of losing their jobs and the lack of education and income to move elsewhere or find work elsewhere, they often suffer from being exploited and do not share their issues with us, the JS or anyone who can help them".

(Anonymous 2, 2019)

While discussing the new strategies or facilities to protect victims or women at the panchayat, another respondent said that

"There is increasing violence against girls, children and elderly in our panchayat. Since the adults go to work mainly in tea plantations, girls are alone in their houses and suffer from a form of sexual assault mostly from a person known to them. To prevent such crimes, we have implemented a new scheme in our panchayat in recent years: it is called Pakalveedu (daycare home). From 7 am to 5 pm, girls, children and the elderly who do not have anyone to look after them at home can come and sit in this day home and return to their own home in the evening when family members return from work. We provide breakfast, lunch and snacks to the people who come to the house during the day, and a doctor has been appointed to take care of the people and assist them. Thus, as a panchayat authority, we are working to prevent violence and sexual exploitation of children and girls alone at home and ensure their protection". 
In terms of finding the main reason for increasing crimes against women in their panchayat and the JS activity to prevent such incidences, another respondent said that

\begin{abstract}
"One of the major problems among the male community in our panchayat is alcohol addiction and various drug usage. Therefore, multiple forms of abuse against women and girls occurring at home by men inside their family are very high. The panchayat authorities and the members of each ward are paying close attention to solve this problem. As a ward member, I often have the freedom to discuss with family members and tell them what they should do and should not do, but most of the time, the male members do not listen to our guidance. As a JS member in my ward, I use to report crimes to the panchayat JS promptly and, if necessary, inform the police”.
\end{abstract}

(Anonymous 4, 2019)

It is also identified that people who are often abused and exploited by their relatives in their community or family are forced to solve problems at home. Their not seeking legal help or informing the JS is a significant obstacle to co-ordinating the JS activities. Therefore, it is vital to increase awareness about reporting any form of crime. While discussing the activities by the JS to raise awareness among people, another respondent said that

\begin{abstract}
"Since this panchayat is inhabited by many Malayalam speaking and Tamil speaking people, it is often a significant challenge to handle matters in both languages when holding JS meetings. However, the JS members try to communicate effectively on time and use translation. When printing notices, we also pay attention to printing them in different languages. This is clear evidence that the JS is working together. In cases where we are unable to reconcile matters, of course, cases are referred to the government's higher authorities and the JS at the district level".
\end{abstract}

(Anonymous 5, 2019)

In any society, it is the responsibility of citizens and other organizations to co-operate with governmental institutions to fulfill public governance. However, 14 respondents acknowledge that even though the JS will encourage clubs or youth organizations, there is a lack of good interest or continuity in such organizational work due to a lack of volunteers. Therefore, in the case of women and girls' protection, the community level activities are also very much appreciated, along with cooperating with different organizations. Thus, another respondent agreed that

"Organizations like Kudumbashree are essential for the early detection and prevention of various forms
of exploitation. The fact that the members of the Kudumbashree know each other and that the women
share the affairs of a household with each other often helps to co-ordinate the matters of the JS and
hence it is a great thing that organizations like Kudumbashree or even their members can bring any
issues to the attention of the panchayat in any home. Also, various religious organizations are working
with the JS to help us with legal action if necessary".

(Anonymous 6, 2019)

While discussing the significant challenge that needs to be tackled for the successful implementation of JS activities, one respondent said that

\begin{abstract}
"One of the problems we often face in co-ordinating and moving forward with JS is financial cooperation and the various sources. The JS has often failed to implement projects, primarily due to the inefficiency and rapid disbursement of funds for social justice projects. People who are hired for counseling by the JS often complain that they are not being paid enough. There is a need to raise a financial base for the JS, and there are barriers to ensuring the protection of women delegates from traveling to attend various programs or sessions of training”.
\end{abstract}

(Anonymous 7, 2019)

The floods of 2018 hit most of the panchayats in the Idukki district drastically. Therefore, panchayats were trying their best to co-ordinate life-saving projects. However, even at that time, there were specific incidences of crimes against women at the flood relief camps and a lack of sufficient toilet facilities or hygiene facilities for women and girls. During these times, too, the JS was actively 
working for women's protection. Most respondents agreed that educational institutions have an essential role in increasing awareness among young generations on the importance of gender equality, women's rights and protection. As educational institutions play a vital role in nurturing a community of socially responsible people, various practical training and defense mechanisms will be put in place to ensure women and girls' safety. While discussing the gender desk and other awareness activities for students, another respondent conveyed that,

\begin{abstract}
"We do our best to organize multiple guidelines for the young boys and girls in the community and create awareness at the school and college level through various programs and seminars. Camps have an essential responsibility to ensure women and girls' protection. Teachers in schools and colleges are responsible for finding out if the girls in their class are mentally or physically abused, giving them the counseling they need and informing the JS of the issues. We provided necessary guidelines at the teacher level as well".
\end{abstract}

(Anonymous 8, 2019)

Even though the dowry system is prohibited by law, dowry issues are still prominent in various panchayats. While discussing the initiatives on preventing such dowry-related crimes, another respondent said that

\begin{abstract}
"We have noticed that the dowry system and related violence is still prominent in our society. Especially economically backward girls suffer violence by their husband's parents in the husband's family after marriage. Such issues are brought to the notice of the JS of this panchayat. Therefore, we provide guidelines in the gram sabha for men to stop the dowry system and encourage women and men to inform the JS secretly if they notice any such cases in their area. We have a letterbox in the panchayat (in Malayalam parathi petty). Anyone can write a letter to us anonymously. We open this letterbox every week and take actions accordingly by discussing and investigating the issue secretly. We will involve the police or women's commission depending on the severity of the situation".
\end{abstract}

(Anonymous 9, 2019)

While discussing the increasing number of cybercrimes against women in Kerala, another respondent said the JS activities that they are undertaken in their panchayat to prevent cyberviolence,

\begin{abstract}
"Cybercrimes are critical issues that we face nowadays; often, misuse of photos of women and girls increases. Therefore, the JS has informed the people to be vigilant and prevent such tendencies and take police guidance. However, in most cases, we cannot find the culprits properly as these types of cybercrimes are often perpetrated through fake accounts. Still, the JS is working very effectively to punish the obscene display and anti-women tendencies by law, especially by presenting sanctions to such kind of posters or announcement if any".
\end{abstract}

(Anonymous 10, 2019)

Violence against women, including intimate partner violence and sexual assault, is a severe problem of society. Data collected by the World Health Organization (WHO, 2017) demonstrate that about a third of women in the world have experienced physical and sexual intimate partner violence or non-partner sexual violence in their lifetime. Women are more likely to experience domestic violence if they have low education, have had mothers abused by partners, have been abused during childhood and have positive attitudes toward violence and male privilege. There is a proven link between advocacy and empowerment counseling interventions and reducing intimate partner violence against women. This study highlights the fact that the Jagratha Samiti activities are of paramount importance in each panchayat in the context of increasing violence against women and children. The awareness programs conducted under the JS in various panchayats are helpful. We can see that a panchayat is divided into different wards. Each ward has a ward member who oversees it. This ward member is responsible for their corresponding ward's development activities and co-ordinating JS events in their wards. Although the panchayat's JS is responsible for intervening in any forms of abuse or crimes against women and children, it is often noted that the non-cooperation of the victim or their family with the JS is a significant crisis in bringing any crimes to the forefront promptly. 
In most cases, the family is afraid of the community they live in and fear for their kids' future if society is aware of their children's plight. In that case, the ward member is often unable to intervene in such matters as parents can often hide such problems from the JS and the police out of shame and embarrassment that the family and their children could face in the society. Especially when it comes to severe cases such as rape, the family is always hesitant to make official complaints as there will be an outbreak of media news. Therefore, JS activities must include schemes to reduce fears, anxieties and narrow-mindedness of society by imparting social justice knowledge, protecting women and children, and awareness of various aids and legal facilities.

In this study, the JS members also revealed that victims of various forms of physical and mental violence and discrimination often undergo an increase in their socio-economic insecurity. In terms of child abuse victims, they suffer from various forms of psychological trauma. In such cases, the JS always tries to provide them with sufficient care and support through a counseling system. Respondents in this study also revealed that the education, employment and lifestyle of the people living in each panchayat play an essential role in preventing violence in the community. The case of Idukki, among the people working in the plantation sector, often goes unnoticed by the authorities since they are hesitant to make any formal or informal complaint against abuse or discrimination. In some panchayats, the JS activities are yet to be focused on since they need financial assistance for implementing various projects. This study also revealed that women's organizations such as Kudumbashree play an essential role in ensuring social security. Since the Kudumbashree members are often women, the members can discuss issues within their families or neighbouring families and present them to the ward member without delay if the victims of violence are unable or scared to move by themselves.

In some cases, the Kudumbashree leaders were able to report certain crimes in families to the JS, and in this way they were able to intervene with support for the victim. Therefore, organizations like Kudumbashree and various women's movements prevent violence against women and children. The respondents also identified the importance of great responsibility to understand the nature of the violence in a highly confidential manner, without discrimination, to ensure justice for the victim and, if necessary, to bring the police or the women's commission. Therefore, the JS members must act with due diligence and commitment to assess the issues so that the society will have an increase in trust in the activities of the JS in the panchayat.

Drug abuse is seen as one of the main reasons for increased violence against women and children, especially consuming alcohol and other drugs is an increasing concern. The JS and other preventive systems are trying to reduce such issues and ensure safety in society. Since in certain panchayats in Idukki boys in schools are dropping out due to lack of proper care or addiction towards such substances, the JS actively provides guidance and counseling to such children and helps them return to school life. This is also an important achievement of the JS. However, in many places, women's rights are seen as a second category or lower in position. Such categorization is also an important reason for women's mistreatment; therefore, the JS is actively trying to raise awareness of equality and advocate for women's equal rights. The JS must ensure that they keep track of the minutes of the meetings held each time, carry out interventions without interruption and keep victims' privacy. Therefore, this research shows the significance of the JS's active participation in each panchayat to ensure women and girls' safety and equality and prevent violence against women in any society.

\section{Conclusions}

In a country with a large population such as India, it is necessary to solve gender inequality and look at the imbalances. In Indian society, men's active intervention is also crucial to combat violence against women and girls and resolve gender violence. Hence, the JS helps a panchayat get men involved in such measures by various activities. Institutions working with women have guaranteed complete care for pregnant women. The JS can persuade and assist the Local Self Government Institution in resolving JS issues and creating a suitable environment for various projects 
to be completed in the future. Every complaint should be approached with humane consideration and should be resolved without delay. The JS should be held at the block level and once every six months at the district level to discuss the JS issues. Simultaneously, the JS initiates a grievance redressal program and creates a gender desk in schools, and builds relationships with mutual respect and understanding among children. Complaints made to the JS must keep secret, especially the complaint's information and details. Ensuring justice for any complaint from a female party can be accepted and resolving issues without prejudice is also an essential JS activity in a panchayat. From the results it is evident that the JS follows the Government of Kerala's guidelines in most of the panchayats. All the respondents have acknowledged that the JS does have an essential role in preventing violence against women and girls in their panchayat. Implementing new strategies such as increasing awareness about the importance of gender equality from the school level will enable the younger generation to understand the importance of equality, protection of women and girls and men's role in violence prevention. However, there are challenges such as low salaries, skilled officers, especially in counseling, lack sufficient financial assistance from higher institutions for projects; there is also a lack co-operation of victims or their families with filing the case, lack of privacy of the victim, cyber rumors against victims are considered as the biggest challenges for achieving the ultimate aim of the JS. Therefore, this research has found that the JS in a panchayat plays a crucial role in combating violence against women.

\section{References}

1. Ahmad, J., Khan, N., \& Mozumdar, A. (2019). Spousal Violence Against Women in India: A Social-Ecological Analysis Using Data From the National Family Health Survey 2015 to 2016. Journal of Interpersonal Violence, 0886260519881530. https://doi.org/10.1177/0886260519881530

2. Banerjee, P. R. (2014). Dowry in 21 st-Century India: The Sociocultural Face of Exploitation. Trauma, Violence, \& Abuse, 15(1), 34-40. https://doi.org/10.1177/1524838013496334

3. Barnes, K., Bouchama, N., \& Loiseau, E. (n.d.). Shifting wealth, shifting gender relations? Gender inequality and social cohesion in a converging world. 24.

4. Bhattacharyya, R. (2016). Street Violence against Women in India: Mapping Prevention Strategies. Asian Social Work and Policy Review, 10(3), 311-325. https://doi.org/10.1111/aswp.12099

5. Bradley, T., \& Pallikadavath, S. (2013). Dowry and women's lives in Kerala: What has changed in a decade? Contemporary South Asia, 21(4), 444-461. https://doi.org/10.1080/09584935.2013.856379

6. Carbone-Lopez, K., Slocum, L. A., \& Kruttschnitt, C. (2016). "Police Wouldn't Give You No Help": Female Offenders on Reporting Sexual Assault to Police. Violence Against Women, 22(3), $366-396$. https://doi.org/10.1177/1077801215602345

7. Chacko Jose, P. (2020). Kudumbashree: A Comprehensive Social Innovation for Women Empowerment [Chapter]. Handbook of Research on New Dimensions of Gender Mainstreaming and Women Empowerment; IGI Global. https://doi.org/10.4018/978-1-7998-2819-8.ch024

8. Córdova, A., \& Kras, H. (2020). Addressing Violence Against Women: The Effect of Women's Police Stations on Police Legitimacy. Comparative Political Studies, 53(5), 775-808. https://doi.org/10.1177/0010414019879959

9. Crime Against Children. (n.d.). Retrieved 2 January, 2021, from https://old.keralapolice.gov.in/publicinformation/crime-statistics/crime-against-children

10. Crime in India-2018. (2020, 8 May). [Text]. Open Government Data (OGD) Platform India. https://data.gov.in/catalog/crime-india-2018

11. Devika, J., \& Thampi, B. V. (2011). Mobility Towards Work and Politics for Women in Kerala State, India: A View from the Histories of Gender and Space. Modern Asian Studies, 45(5), 1147-1175. https://doi.org/10.1017/S0026749X09000080

12. Fernandez, M. (1997). Domestic Violence by Extended Family Members in India: Interplay of Gender and Generation. Journal of Interpersonal Violence, 12(3), 433-455. https://doi.org/10.1177/088626097012003008

13. George, M. (2011). In the Midst of a Storm: Distress of Kerala Women. Affilia, 26(3), 304-313. https://doi.org/10.1177/0886109911417690

14. Hunnicutt, G. (2009). Varieties of Patriarchy and Violence Against Women: Resurrecting "Patriarchy" as a Theoretical Tool. Violence Against Women, 15(5), 553-573. https://doi.org/10.1177/1077801208331246 
15. Indu, P. V., Remadevi, S., Vidhukumar, K., Shah Navas, P. M., Anilkumar, T. V., \& Subha, N. (2020). Domestic Violence as a Risk Factor for Attempted Suicide in Married Women. Journal of Interpersonal Violence, 35(23-24), 5753-5771. https://doi.org/10.1177/0886260517721896

16. Jejeebhoy, S. J., \& Sathar, Z. A. (2001). Women's Autonomy in India and Pakistan: The Influence of Religion and Region. Population and Development Review, 27(4), 687-712. https://doi.org/10.1111/j.1728-4457.2001.00687.x

17. Jordan, J. (2004). Beyond Belief?: Police, Rape and Women's Credibility. Criminal Justice, 4(1), 29-59. https://doi.org/10.1177/1466802504042222

18. Joseph, N. (2020). Role of Civil Society in Democratic Consolidation Process in Bangladesh In Buildingsustainable-communities (pp. 115-140).

19. Kabeer, N. (1999). Resources, Agency, Achievements: Reflections on the Measurement of Women's Empowerment. Development and Change, 30(3), 435-464. https://doi.org/10.1111/1467-7660.00125

20. Kabeer, N. (2005). Gender equality and women's empowerment: A critical analysis of the third millennium development goal 1. Gender \& Development, 13(1), 13-24. https://doi.org/10.1080/13552070512331332273

21. Kerala Legislature Secretariat. (2015). THE KERALA PANCHAYAT RAJ (AMENDMENT) BILL, 2015.

22. Kudumbashree | Local Self Government Department. (n.d.). Retrieved 3 January, 2021, from http://lsgkerala.gov.in/en/kudumbashree

23. Kudumbashree Story-Community Development Society (CDS). (n.d.). Retrieved 2 January, 2021, from https://thekudumbashreestory.info/index.php/what\%E2\%80\%99s-kudumbashree/community-network/communitydevelopment-society-cds

24. Nair, N. V., \& Moolakkattu, J. S. (2014). Women Component Plan at the Village Panchayat Level in Kerala: Does it Live Up to its Promise? Indian Journal of Gender Studies, 21(2), $247-276$. https://doi.org/10.1177/0971521514525156

25. National Family Health Survey. (n.d.). Retrieved 21 December, 2020, from http://rchiips.org/nfhs/kerala.shtml

26. Nieder, C., Muck, C., \& Kärtner, J. (2019). Sexual Violence Against Women in India: Daily Life and Coping Strategies of Young Women in Delhi. Violence Against Women, 25(14), 1717-1738. https://doi.org/10.1177/1077801218824056

27. Official Webportal of Idukki District Police. (n.d.). Public-information. Retrieved 29 January, 2021, from https://idukki.keralapolice.gov.in/public-information/crime-statistics/crime-against-women

28. Official Webportal of Kerala Police. (n.d.). Crime Against Children. Retrieved 30 January, 2021, from https://old.keralapolice.gov.in/public-information/crime-statistics/crime-against-children

29. Official Website of Kerala Police. (n.d.). Retrieved 2 January, 2021, from https://keralapolice.gov.in/page/crimeagainst-women

30. Rastogi, M., \& Therly, P. (2006). Dowry and Its Link to Violence Against Women in India: Feminist Psychological Perspectives. Trauma, Violence, \& Abuse, 7(1), 66-77. https://doi.org/10.1177/1524838005283927

31. Rudd, J. (2001). Dowry-murder: An example of violence against women. Women's Studies International Forum, 24(5), 513-522. https://doi.org/10.1016/S0277-5395(01)00196-0

32. Schemes-WCD Kerala. (n.d.). Retrieved 28 January, 2021, from http://wcd.kerala.gov.in/serviceinfo.php?service_category_sl=MTI=

33. Sharma, B. R., Harish, D., Gupta, M., \& Singh, V. P. (2005). Dowry - A Deep-Rooted Cause of Violence Against Women in India. Medicine, Science and the Law, 45(2), 161-168. https://doi.org/10.1258/rsmmsl.45.2.161

34. Subair, K. (2017). Efficacy of Implementation of Panchayat Jagrata Samiti: A Case Study of Kozhikode District, Kerala (India). International Journal of Research -GRANTHAALAYAH, 5(12), 112-120. https://doi.org/10.29121/granthaalayah.v5.i12.2017.479

35. Sunny, C. (2003). Domestic violence against women-Report on a situational analysis in Ernakulum district, Kerala. Social Change, 33(1), 26-54. https://doi.org/10.1177/004908570303300102

36. United Nations, B. D. (n.d.). Beijing Declaration. Retrieved 30 January, 2021, from https://www.un.org/womenwatch/daw/beijing/platform/declar.htm

37. Usha, K. (2012). Role of Panchayat Bodies in Rural Development: How to Improve the Functioning of Panchayat Institutions. Indian Journal of Public Administration, 58(4), 707-718. https://doi.org/10.1177/0019556120120407

38. Venugopal, V., \& Yilmaz, S. (2009). Decentralization in Kerala: Panchayat government discretion and accountability. Public Administration and Development, 29(4), 316-329. https://doi.org/10.1002/pad.541

39. WHO. (2017). Violence against women. https://www.who.int/news-room/fact-sheets/detail/violence-againstwomen 
Titty Varghese

\section{Panchayat Jagratha Samithi vaidmuo dėl smurto prieš moteris ir vaikus Keraloje}

\section{Anotacija}

Indijos Keralos valstija garsèja savo ekonomine ir socialine plètra, išskirtinai yra vertinama visuomenès raidos, lygybès ir švietimo rodikliai. Tačiau kovojant su smurtu prieš moteris ir mergaites valstybès politika neatitinka darnios plètros tikslų. Bendras nusikaltimų prieš moteris skaičius Keraloje 2007 m. siekè 9381, 2019 m. pabaigoje jis išaugo iki 13925, o iki 2020 m. spalio mèn. Buvo įvykdyta net 10124 nusikaltimai prieš moteris. Valstybè, siekdama užkirsti kelią visų rūšių nusikaltimams moterims, $1997 \mathrm{~m}$. įsteigè komitetą, kurio veiklą kuruoja Keralos moterų komisija. Šis komitetas yra žinomas kaip Jagratha Samithi (malajų kalba) ir dirba kiekvienoje vietos savivaldoje (Panchayat). Šio tyrimo objektas yra Jagratha Samithi. Tyrimo tikslas yra nustatyti Jagratha Samithi vaidmenį ir veiklą Pančajate, siekiant užkirsti kelią smurtui prieš moteris ir mergaites. Tyrimo metodika pagrịsta kokybiniu tyrimu, kurio pirminiai duomenys surinkti iš 40 išrinktų moterų ir vyrų atstovų iš 35 Pančajatų Keraloje. Tyrimas rodo, kad Jagratha Samithi Pančajate vaidina svarbų vaidmenį sprendžiant nusikaltimus prieš moteris ir mergaites. Tačiau trūksta pakankamos visuomenès paramos jos misijai.

Titty Varghese - doctoral candidate in the social science, Kaunas University of technology, Lithuania E-mail: titty.varghese@ktu.lt

Titty Varghese - socialinių mokslų doktorantė Kauno technikos universitete, Lietuva El. paštas: titty.varghese@ktu.lt 